\title{
INFLUENCE OF NITROGEN AND ORGANIC FERTILIZATION ON GROWTH, YIELD AND QUALITY OF SUGAR BEET GROWN IN CALCAREOUS SOIL.
}

Hasanen, G. H. ; I. H. Elsokkary ${ }^{* *}$; M. Z. Kamel ${ }^{* * *}$ and

A. M. Abd Elsamea***

* Soils and Water Dep., Fac. Agric., Assiut Univ.

** Soils and Water Dep., Fac.Agric., Alexandria Univ.

*** Nobaria Sugar and Refining Company

\begin{abstract}
The present investigation was carried out during the growth season of 20112012 at Nobaria Sugar and Refining Company, El-Bohera Governorate to evaluate the influence of $\mathrm{N}$ - fertilization on yield and quality of sugar beet grown in calcareous soil. Split plot design with 3 replicates with 8 treatments, four rates of nitrogen fertilizer were spread in the main plot, while the sub plots were assigned for the two organic fertilizers. The result obtained showed significant increase in shoot fresh weight, root fresh weight, root length, root yield and sugar yield in plants with increasing fertilization up to $350 \mathrm{~kg} \mathrm{~N} / \mathrm{fed}$. Organic fertilization by farmyard manure (FYM) and poultry manure (PM) was tested. The yield of these attributes of sugar beet was increased but the estimating effect was higher for PM than FYM. The technological characters of sugar beet (Sugar percentage, Purity, K, Na and Alfa-amino-N) rose with increasing $\mathrm{N}$ fertilization rate with application of PM or FYM. Under conditions of the present work, supplying sugar beet with $350 \mathrm{~kg} \mathrm{~N} / \mathrm{fed}$ with FYM or PM resulted in the highest root and sugar yields/fed.
\end{abstract}

Keywords: Sugar beet - Nitrogen- farmyard manure - poultry manure - growth sugar yield- Root yield

\section{INTRODUCTION}

Sugar beet is the second sugar crop after sugar cane for the production process of sugar in Egypt. Yield and quality of sugar beet depend mostly on a number of important factors such as plant variety, soil physical and chemical properties, plant nutrients requirements and climate. Sugar beet fertilization aims to achieve high yields of both beet and sugar. Fertilization especially with nitrogen in particular must aim to balance between large yield of root and large sugar content. There is knowledge of nutrients requirements and fertilization programs would lead to acceptable quantity and quality of root and sugar yield. High yield of sugar beet requires adequate nutrients balance and water supply during the growth period. However, both low available of nutrients and low water supply seems to be indicated powers the end space of vegetative growth period. It has been found that increasing $\mathrm{N}$ fertilization rate up to $92 \mathrm{~kg} / \mathrm{fed}$ had significantly increased root fresh weight, root and sugar yield but decreased sucrose percentage (EL-Shafai, 2000 and Ismail and Abo El-Ghait, 2004). In earlier study, also (Besheit et al., 1994) found that applying $N$ up to $150 \mathrm{~kg} / \mathrm{fed}$ to sugar beet grown on sandy soil significantly increased root weight of plant and sugars yield/fed. Application of organic fertilization has been applied to 
estimate plant growth and yield, and a combination of farmyard manure, with mineral $\mathrm{N}$ increased root and sugar yields. It has been reported that organic compost with $\mathrm{N}$ mineral fertilizer significantly increased leaf blade length, leaf blade width, leaf petiole length, leaves no per plant, leaves fresh and dry weights, root length, root diameter, root weight and root yield (EL-Geddawy et al., 2003). Kristaponyte, (2003) found that applying (FYM) in combination value $\mathrm{N}$ significantly increased root diameter, root length, root fresh weight and root dry weight.

Therefore, the objective of this study was to evaluate the effect of different levels of nitrogen fertilization under FYM or PM on yield and quality of sugar beet grown in calcareous soil.

\section{MATERIALS AND METHODS}

Field experiment was carried out at Nobaria Sugar and Refining Company, El-Bohera government during 2011-2012 growing season. This work included eight treatments represent the combinations between nitrogen levels and two organic fertilizers (FYM and PM). The main chemical and physical characteristics of the soil shown in (Table 1) and the metrological data of the experimental site according to Chapman and Praft (1961) were shown in (Table 2). $\mathrm{N}$ fertilizer was added in the form of Ammonium nitrate $(33.5 \% \mathrm{~N})$; while the organic fertilization was added at $21 \mathrm{~m}^{3} / \mathrm{fed}$ at tillage through preparing the experimental site (Table 3).

Table 1. The average value of the main chemical and physical characteristic of the experimental soil

\begin{tabular}{|c|c|c|c|c|c|}
\hline $\begin{array}{l}\text { Soil } \\
\text { parameter }\end{array}$ & $\begin{array}{l}\text { Soil depth } \\
\text { (cm) }\end{array}$ & Values & $\begin{array}{l}\text { Soil } \\
\text { parameter }\end{array}$ & $\begin{array}{c}\text { Soil } \\
\text { depth } \\
\text { (cm) }\end{array}$ & Values \\
\hline$\overline{E C(d s / m)}$ & $\begin{array}{c}0-15 \\
15-30\end{array}$ & $\begin{array}{l}0.10 \\
0.15\end{array}$ & OM (\%) & $\begin{array}{c}0-15 \\
15-30\end{array}$ & $\begin{array}{l}0.06 \\
0.08\end{array}$ \\
\hline PH & $\begin{array}{c}0-15 \\
15-30\end{array}$ & $\begin{array}{l}8.2 \\
8.4\end{array}$ & Total $\mathrm{Co}_{3}^{-2}(\%)$ & $\begin{array}{c}0-15 \\
15-30\end{array}$ & $\begin{array}{l}4.9 \\
5.8\end{array}$ \\
\hline Water soluble : & & & Particle size distribution & & \\
\hline $\mathrm{N}(\mathrm{mg} / 100 \mathrm{~g}$ soil) & $\begin{array}{c}0-15 \\
15-30\end{array}$ & $\begin{array}{l}2.1 \\
2.8\end{array}$ & Sand $(\%)$ & $\begin{array}{c}0-15 \\
15-30\end{array}$ & $\begin{array}{l}92.0 \\
92.0\end{array}$ \\
\hline$P(\mathrm{mg} / 100 \mathrm{~g}$ soil) & $\begin{array}{c}0-15 \\
15-30\end{array}$ & $\begin{array}{l}0.2 \\
0.1\end{array}$ & Silt (\%) & $\begin{array}{c}0-15 \\
15-30\end{array}$ & $\begin{array}{l}4.0 \\
4.0\end{array}$ \\
\hline $\mathrm{Ca}^{+2}(\mathrm{mg} / 100 \mathrm{~g}$ soil) & $\begin{array}{c}0-15 \\
15-30\end{array}$ & $\begin{array}{l}40.0 \\
40.0\end{array}$ & Clay (\%) & $\begin{array}{c}0-15 \\
15-30\end{array}$ & $\begin{array}{l}4.0 \\
4.0\end{array}$ \\
\hline $\mathrm{Mg}^{+2}(\mathrm{mg} / 100 \mathrm{~g}$ soil $)$ & $\begin{array}{c}0-15 \\
15-30\end{array}$ & $\begin{array}{l}23.0 \\
18.0\end{array}$ & Texture class & $\begin{array}{c}0-15 \\
15-30\end{array}$ & $\begin{array}{l}\text { Sandy } \\
\text { Sandy }\end{array}$ \\
\hline $\mathrm{K}^{+}$(mg/100g soil) & $\begin{array}{c}0-15 \\
15-30\end{array}$ & $\begin{array}{l}16.0 \\
5.0\end{array}$ & $\begin{array}{l}\text { Moisture } \% \text { by volume } \\
\text { F.C }\end{array}$ & $0-15$ & 13.25 \\
\hline $\mathrm{Na}^{+}(\mathrm{Mg} / 100 \mathrm{~g}$ soil $)$ & $\begin{array}{c}0-15 \\
15-30\end{array}$ & $\begin{array}{l}6.0 \\
5.0\end{array}$ & W.P & $\begin{array}{c}15-30 \\
0-15\end{array}$ & $\begin{array}{c}14.25 \\
5.5\end{array}$ \\
\hline SAR & $\begin{array}{c}0-15 \\
15-30\end{array}$ & $\begin{array}{l}1.66 \\
1.74\end{array}$ & Available water & $\begin{array}{c}15-30 \\
0-15 \\
15-30\end{array}$ & $\begin{array}{c}4.9 \\
7.75 \\
9.35\end{array}$ \\
\hline
\end{tabular}


Split plot design with three replications was used. $\mathrm{N}$ fertilizer levels were spread in the main plots; organic fertilizers were distributed in the sub plots. Two seeds of sugar beet (Beta vulgaris) variety Kawmmeira were sown manually on September $29^{\text {th }}, 2011$ with $0.01 \mathrm{~m}$ planting space and $0.5 \mathrm{~m}$ between rows. After thirty days from sowing the seedlings was thinned to one plant per hill. The field experimental area was $3150 \mathrm{~m}^{2}$, divided into two equal fields of $1575 \mathrm{~m}^{2}$ for each organic fertilizer (6 plants $\left./ \mathrm{m}^{2}\right)$. Super phosphate fertilizer $\left(15.5 \% \mathrm{P}_{2} \mathrm{O}_{5}\right)$ was added to the soil at rate of $150 \mathrm{~kg} / \mathrm{fed}$ during land preparation and mixed in the plow layer. Ammonium nitrate fertilizer was applied at a rate of $(0,150,250$ and $350 \mathrm{~kg} / \mathrm{fed})$ in five equal doses. The first dose was applied after plant thinning and the other doses were added at 45 days interval. Potassium sulfate fertilizer $\left(48 \% \mathrm{~K}_{2} \mathrm{O}\right)$ was applied at a rate of $50 \mathrm{Kg} / \mathrm{fed}$ in two equal doses. Both ammonium nitrate and potassium sulfate BerAlzero were applied with water of irrigation (Fertigation).

Table 2. Average value of meteorological data of the experimental site

\begin{tabular}{lccccc}
\hline Month & $\begin{array}{c}\text { Max } \\
\text { Temp }^{0} \mathbf{C}\end{array}$ & $\begin{array}{c}\text { Min } \\
\text { Temp }\end{array}$ & Humidity \% & Wind speed (km/d) & $\begin{array}{c}\text { Sunshine } \\
\text { (Hrs.) }\end{array}$ \\
\hline October, 2011 & 29.68 & 16.74 & 51.81 & 199.74 & 9.3 \\
November, 2011 & 23.13 & 12.03 & 59.37 & 189.60 & 8.0 \\
December, 2011 & 22.10 & 11.44 & 60.97 & 213.10 & 6.7 \\
January, 2012 & 18.29 & 8.13 & 52.10 & 256.26 & 7.0 \\
February, 2012 & 18.90 & 8.34 & 51.55 & 254.90 & 7.7 \\
March, 2012 & 22.45 & 9.77 & 51.06 & 294.19 & 8.6 \\
April, 2012 & 28.00 & 13.53 & 49.77 & 216.00 & 9.7 \\
Average & 23.22 & 11.43 & 53.80 & 231.97 & 8.14 \\
\hline
\end{tabular}

Table 3. Main constitution and nutrients in farm yard manure (FYM) and poultry manure (PM) as percentage of weight basis

\begin{tabular}{lcc}
\hline Parameter & FYM & PM \\
\hline Humidity & 81.1 & 57.0 \\
Organic matter & 12.7 & 29.3 \\
Mineral matter & 5.3 & - \\
$\mathbf{N}$ & 0.26 & 1.46 \\
$\mathbf{P}$ & 0.18 & 1.17 \\
K & 0.17 & 0.62 \\
Lime & 0.46 & - \\
\hline
\end{tabular}

Artesian water was used for irrigation and fertilization by mean of drip irrigation technique. The total amount of irrigation water applied during the growth period ( 210 day) was $2980 \mathrm{~m}^{3} / \mathrm{fed}$. This amount of irrigation was divided into 32 doses during the growth period from sowing to harvesting. The main chemical characteristic water of irrigation is shown in (Table 4). 
Hasanen, G. H. et al.

Table 4. Chemical characteristics of irrigation water

\begin{tabular}{|c|c|c|c|}
\hline Parameter & values & Parameter & values \\
\hline TDS (mg/L) & 345.6 & Water soluble & \\
\hline Water soluble & & $\mathrm{Co}_{3}{ }^{-2}$ (meq/L) & n.d \\
\hline $\mathrm{Ca}^{+2}(\mathrm{meq} / \mathrm{L})$ & 2.0 & $\mathrm{HCO}_{3}^{-}(\mathrm{meq} / \mathrm{L})$ & 1.3 \\
\hline $\mathrm{Mg}^{+2}(\mathrm{meq} / \mathrm{L})$ & 1.0 & $\mathrm{Cl}^{-}$ & 1.25 \\
\hline $\mathrm{K}^{+} \quad(\mathrm{meq} / \mathrm{L})$ & 0.16 & $\mathrm{So}_{4}{ }^{-2}$ & 2.98 \\
\hline $\mathrm{Na}+(\mathrm{meq} / \mathrm{L})$ & 2.37 & SAR & 12.1 \\
\hline
\end{tabular}

n.d: not detected.

Samples of plants (6 plants) were collected at 28,85 and 210 days from sowing for measurement fresh weight of shoot $\left(\mathrm{g} / \mathrm{m}^{2}\right)$, fresh weight of root $\left(\mathrm{g} / \mathrm{m}^{2}\right)$ and root length $(\mathrm{cm})$. At harvest, sucrose percentage (AOAC, 1980), apparent purity percentage, $\mathrm{N}^{+}$percentage, $\mathrm{K}^{+}$percentage, alfaamino-N percentage, sucrose percentage, Root yield(t/fed) and sugar yield $(\mathrm{t} / \mathrm{fed})$ were also determined. The obtained data were statistically analyzed according to the technique of analysis of variance (ANOVA) of the split plot design as described by (Gomez and Gomez, 1984). The mean values were compared according to least significant difference (L.S.D).

\section{RESULTS AND DISCUSSION}

\section{Growth and yield characters}

Shoot Fresh Weight (SFW): Data in Table 5 showed that significant increase in shoot fresh weight of sugar beet plants were achieved with increase $\mathrm{N}$ application in combination with FYM up to $250 \mathrm{~kg} \mathrm{~N} / \mathrm{fed}$ for 28 days age plants, while 85 and 210 days age plants showed significant increase with increasing $\mathrm{N}$ rate up to $350 \mathrm{~kg} \mathrm{~N} / \mathrm{fed}$. Similar trend was found with increasing $\mathrm{N}$ application rate in combination with PM. This result is in agreement with that reported by Leilah et al., (2005), who mentioned that increasing $\mathrm{N}$ level up to $250 \mathrm{~kg} \mathrm{~N} / \mathrm{fed}$ produced significantly higher values of shoot fresh weight. It is clear that organic fertilization by (PM) without $\mathrm{N}$ application produced significant in shoot fresh weight of sugar beet plants than (FYM) especially at 210 day sage plants. The effect of (PM) on (SFW) was more than that (FYM) especially at high rates of $\mathrm{N}$ application (250 and $350 \mathrm{~kg} \mathrm{~N} / \mathrm{fed}$ ) and at older plants (210 days age) than young plants (28 days age). The values of the relative variation (R.V.\%) in shoot fresh weight of sugar beet plants (Table 6) indicated that increasing $\mathrm{N}$ application had increase in shoot fresh weight of sugar beet plants with longer rate of younger (28 days) than older ( 210 day) plants. It is also clear that the value of utile values rate had decreased until plant age. This data indicates that the estimating effect of $\mathrm{N}$ on the growth of plant is higher at the earlier growth stages of plants than at late growth stage of plants. Data in Table 7 showed that the value of relative growth rate (RGR) were laughed for young plants (28 days) than old plants (210 day) this in decades progressive rate of increase in the growth of sugar beet plant during the early growth period (between 28 and 85 days) than decreased by proceeding plant age (85-210 
day). It is also clear that increasing $N$ fertilizer application rate had decreased the value of (RGR) especially at earlier growth stage (28 day) but this decrease was not significant. It is also clear that there were no significant variation the values of RGR as a result of FYM and PM application during the three growth pended of sugar beet plant. The estimating action of PM was more effective at higher dose of applied $\mathrm{N}$ fertilizes than at low $\mathrm{N}$ fertilizer application.

Table 5. Shoot fresh weight $\left(\mathrm{gm} / \mathrm{m}^{2}\right)$ of sugar beet plant as influence by nitrogen and organic fertilizer treatments for samples collected after 28,85 and 210 days form sowing.

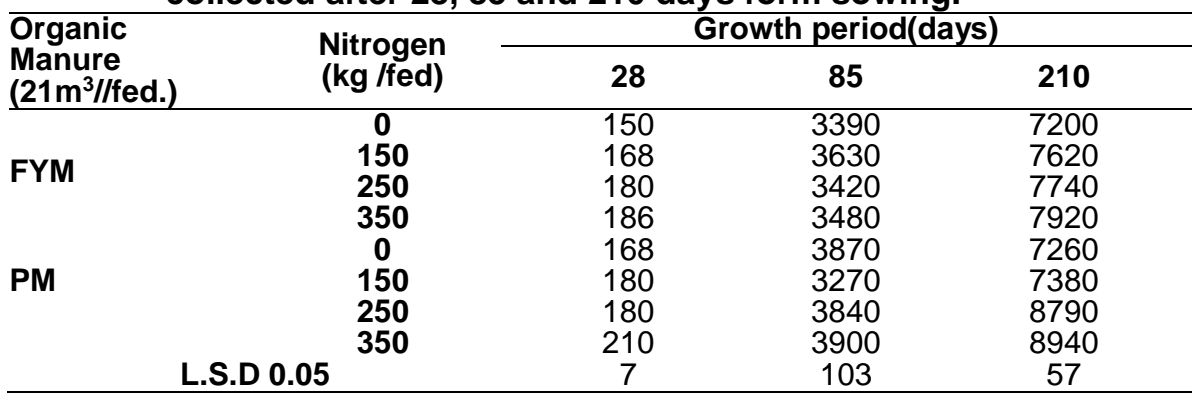

Table 6. Relative variation (R.V. \%) in SFW as a result of $\mathrm{N}$ and manure fertilization

\begin{tabular}{|c|c|c|c|c|}
\hline \multirow{2}{*}{$\begin{array}{l}\text { Organic } \\
\text { Manure } \\
\left(21 \mathrm{~m}^{3} / / \mathrm{fed} .\right)\end{array}$} & \multirow{2}{*}{$\begin{array}{l}\text { Nitrogen } \\
\text { (kg/fed) }\end{array}$} & \multicolumn{3}{|c|}{ Growth period(days) } \\
\hline & & 28 & 85 & 210 \\
\hline FYM & $\begin{array}{c}0 \\
150 \\
250 \\
350\end{array}$ & $\begin{array}{l}- \\
+12.0 \\
+7.1 \\
+3.3\end{array}$ & $\begin{array}{l}- \\
+7.1 \\
-5.7 \\
+1.7\end{array}$ & $\begin{array}{l}- \\
+5.8 \\
+1.5 \\
+2.3\end{array}$ \\
\hline PM & $\begin{array}{c}0 \\
150 \\
250 \\
350\end{array}$ & $\begin{array}{c}-\overline{-} \\
+7.1 \\
0.0 \\
+16.6\end{array}$ & $\begin{array}{l}- \\
-15.5 \\
+17.4 \\
+1.5\end{array}$ & $\begin{array}{r}- \\
+1.6 \\
+19.1 \\
+1.7\end{array}$ \\
\hline
\end{tabular}

Table 7. Relative growth rate (RGR) of shoot $\left(\mathrm{gm} / \mathrm{m}^{2} / \mathrm{day}\right)$ of sugar beet plant as influence by nitrogen and organic fertilizer treatments.

\begin{tabular}{|c|c|c|c|c|}
\hline \multirow{2}{*}{$\begin{array}{l}\text { Organic } \\
\text { Manure } \\
\left(21 \mathrm{~m}^{3} / / \text { fed.) }\right.\end{array}$} & \multirow{2}{*}{$\begin{array}{l}\text { Nitrogen } \\
\text { (kg /fed) }\end{array}$} & \multicolumn{3}{|c|}{ Growth period(days) } \\
\hline & & 28 & 85 & 210 \\
\hline $\begin{array}{l}\text { PM } \\
\text { LSD } 0.05\end{array}$ & $\begin{array}{l}0 \\
150 \\
250 \\
350 \\
0 \\
150 \\
250 \\
350\end{array}$ & $\begin{array}{l}0.055 \\
0.054 \\
0.052 \\
0.051 \\
0.055 \\
0.051 \\
0.054 \\
0.051 \\
0.018 \\
\end{array}$ & $\begin{array}{l}0.006 \\
0.006 \\
0.007 \\
0.007 \\
0.005 \\
0.007 \\
0.007 \\
0.007 \\
0.018 \\
\end{array}$ & $\begin{array}{l}0.021 \\
0.021 \\
0.021 \\
0.021 \\
0.021 \\
0.020 \\
0.021 \\
0.021 \\
0.018 \\
\end{array}$ \\
\hline
\end{tabular}




\section{Root Fresh Weight (RFW)}

Data in Table 8 showed significant increase in root fresh weight (RFW) of sugar beet plant as a result of increasing rate of applied $\mathrm{N}$ in the presence of FYM and PM. These findings coincide with those declared by Leilah et al., (2005), who mentioned that increasing $N$ fertilizer level raise high value of root fresh weight.

Table 8. Root fresh weight $\left(\mathrm{gm} / \mathrm{m}^{2}\right)$ of sugar beet plant as influence by nitrogen and organic fertilizer treatments after 28, 85 and 210 day from sowing.

\begin{tabular}{|c|c|c|c|c|}
\hline \multirow{2}{*}{$\begin{array}{l}\text { Organic } \\
\text { Manure } \\
\left(21 \mathrm{~m}^{3} / / \mathrm{fed} .\right)\end{array}$} & \multirow{2}{*}{$\begin{array}{l}\text { Nitrogen } \\
\text { (kg /fed) }\end{array}$} & \multicolumn{3}{|c|}{ Growth period(days) } \\
\hline & & 28 & 85 & 210 \\
\hline \multirow{4}{*}{ FYM } & 0 & 132 & 2070 & 4260 \\
\hline & 150 & 144 & 2100 & 4290 \\
\hline & 250 & 150 & 2460 & 7560 \\
\hline & 350 & 168 & 2730 & 4680 \\
\hline \multirow{4}{*}{ PM } & 0 & 144 & 2400 & 4350 \\
\hline & 150 & 156 & 2130 & 380 \\
\hline & 250 & 168 & 2520 & 4710 \\
\hline & 350 & 192 & 2670 & 5070 \\
\hline LSD 0.05 & & 4 & 91 & 64 \\
\hline
\end{tabular}

Data in Table 9 showed that the rate of the relative growth rate (RGR) of Root F.W were higher in young plants (28-85 days) than older plants (85-210 days)

It seem that no significant variation in the rates of RGR of the RFW as a result of increasing rates of applied $\mathrm{N}$ as a result of organic fertilization by FYM and PM.

Table 9. Relative growth rate (RGR) of root sugar beet plant ( $\mathrm{gm} / \mathrm{m}^{2} /$ day)

\begin{tabular}{|c|c|c|c|c|}
\hline \multirow{2}{*}{$\begin{array}{l}\text { Organic } \\
\text { Manure } \\
\left(21 \mathrm{~m}^{3} / / \text { fed.) }\right.\end{array}$} & \multirow{2}{*}{$\begin{array}{l}\text { Nitrogen } \\
\text { (kg/fed) }\end{array}$} & \multicolumn{3}{|c|}{ Growth period(days) } \\
\hline & & 28 & 85 & 210 \\
\hline FYM & $\begin{array}{c}0 \\
150 \\
250 \\
350\end{array}$ & $\begin{array}{l}0.048 \\
0.047 \\
0.049 \\
0.049\end{array}$ & $\begin{array}{l}0.006 \\
0.006 \\
0.005 \\
0.004\end{array}$ & $\begin{array}{l}0.019 \\
0.019 \\
0.019 \\
0.018\end{array}$ \\
\hline \multirow[t]{2}{*}{ PM } & $\begin{array}{c}0 \\
150 \\
250 \\
350\end{array}$ & $\begin{array}{l}0.049 \\
0.046 \\
0.048 \\
0.046\end{array}$ & $\begin{array}{l}0.005 \\
0.006 \\
0.005 \\
0.005\end{array}$ & $\begin{array}{l}0.019 \\
0.018 \\
0.018 \\
0.018\end{array}$ \\
\hline & & 0.018 & 0.018 & 0.018 \\
\hline
\end{tabular}

Data in Table 10 showed that the values of the relative variation in root fresh weight (RFW) have been increase with increasing $N$ application rate. However, these increases were higher with the highest $\mathrm{N}$ dose for 28 
and 85 days old plants and were the highest with $\mathrm{N}$ dose of $250 \mathrm{~kg} \mathrm{~N} / \mathrm{fed}$ with 210 days old plants.

It is also clear from Table 10 that the values of relative increase in RFW were as the average almost higher with application of PM than FYM. These data point out to the effective role of PM for statically TFW than that of FYM in the presence of $\mathrm{N}$ fertilization.

Table 10. Relative variation (R.V. \%) in total fresh weight as a result of $\mathbf{N}$ and organic manure fertilization.

\begin{tabular}{|c|c|c|c|c|}
\hline \multirow{2}{*}{$\begin{array}{l}\text { Organic } \\
\text { Manure } \\
\left(21 \mathrm{~m}^{3} / / \mathrm{fed} .\right) \\
\end{array}$} & \multirow{2}{*}{$\begin{array}{c}\text { Nitrogen } \\
\text { (kg/fed) }\end{array}$} & \multicolumn{3}{|c|}{ Growth period(days) } \\
\hline & & 28 & 85 & 210 \\
\hline FYM & $\begin{array}{c}0 \\
150 \\
250 \\
350\end{array}$ & $\begin{array}{r}+9.0 \\
+4.1 \\
+12.0\end{array}$ & $\begin{array}{l}+1.4 \\
+17.1 \\
+11.0\end{array}$ & $\begin{array}{l}+0.7 \\
+6.2 \\
+2.6\end{array}$ \\
\hline PM & $\begin{array}{c}0 \\
150 \\
250 \\
350 \\
\end{array}$ & $\begin{array}{c}- \\
+8.3 \\
+7.6 \\
+14.2\end{array}$ & $\begin{array}{c}- \\
-11.2 \\
+18.3 \\
+6.0\end{array}$ & $\begin{array}{l}- \\
+6.0 \\
+7.5 \\
+7.6\end{array}$ \\
\hline
\end{tabular}

Root length ( $R L)$

Data in Table 11 showed significant increase in root length of sugar beet plants with increasing rate of applied $\mathrm{N}$ with either FYM or PM application. The values of root length were almost higher in older plants (210 day) than either 85 days or 28 days plants. It is also clear that the values of root length were significantly higher for plant treated with PM and for plant treated with FYM at each rate of $\mathrm{N}$ applied. These results are in accordance with that of (Seadh et al., 2007) showed that increasing nitrogen fertilizer level significantly increased all studied growth characters, especially root length.

Table 11. Root length (cm) of sugar beet plant as influence by nitrogen and organic fertilizer treatments at 28,85 and 210 days from sowing.

\begin{tabular}{|c|c|c|c|c|}
\hline \multirow{2}{*}{$\begin{array}{l}\text { Organic } \\
\text { Manure } \\
\left(21 \mathrm{~m}^{3} / / \text { fed.) }\right.\end{array}$} & \multirow{2}{*}{$\begin{array}{l}\text { Nitrogen } \\
\text { (kg/fed) }\end{array}$} & \multicolumn{3}{|c|}{ Growth period(days) } \\
\hline & & 28 & 85 & 210 \\
\hline FYM & $\begin{array}{c}0 \\
150 \\
250 \\
350\end{array}$ & $\begin{array}{c}8.0 \\
8.0 \\
11.0 \\
13.0\end{array}$ & $\begin{array}{l}15.0 \\
21.0 \\
23.0 \\
25.0\end{array}$ & $\begin{array}{l}17.0 \\
24.0 \\
29.0 \\
31 . .0\end{array}$ \\
\hline \multirow[t]{2}{*}{ PM } & $\begin{array}{c}0 \\
150 \\
250 \\
350\end{array}$ & $\begin{array}{l}10.0 \\
12.0 \\
13.0 \\
15.0\end{array}$ & $\begin{array}{l}18.0 \\
26.0 \\
28.5 \\
29.0\end{array}$ & $\begin{array}{l}21.0 \\
27.0 \\
32.0 \\
34.0\end{array}$ \\
\hline & & 3.0 & 3.0 & 1.5 \\
\hline
\end{tabular}


Data in Table 12 showed that the values of RGR of root length were almost higher at earlier plant (28 day) than at 85 and 210 days old plants. These values were almost higher for plants treated with PM than for there treated with FYM. This data indicate higher efficiency of PM for estimating the root length of sugar beet plant with each rate of applied $\mathrm{N}$.

Table 12. Relative growth rate (RGR) of root length (cm/day) of sugar beet plant as influence by nitrogen and organic fertilizer treatments.

\begin{tabular}{|c|c|c|c|c|}
\hline \multirow{2}{*}{$\begin{array}{l}\text { Organic } \\
\text { Manure } \\
\left(21 \mathrm{~m}^{3} / / \text { fed.) }\right.\end{array}$} & \multirow{2}{*}{$\begin{array}{l}\text { Nitrogen } \\
\text { (kg/fed) }\end{array}$} & \multicolumn{3}{|c|}{ Growth periods (days) } \\
\hline & & 28-85 & $85-210$ & $28-210$ \\
\hline FYM & $\begin{array}{c}0 \\
150 \\
250 \\
350\end{array}$ & $\begin{array}{l}0.011 \\
0.017 \\
0.013 \\
0.011\end{array}$ & $\begin{array}{l}0.001 \\
0.001 \\
0.002 \\
0.002\end{array}$ & $\begin{array}{l}0.004 \\
0.006 \\
0.005 \\
0.005\end{array}$ \\
\hline PM & $\begin{array}{c}0 \\
150 \\
250 \\
350\end{array}$ & $\begin{array}{l}0.010 \\
0.014 \\
0.013 \\
0.012\end{array}$ & $\begin{array}{l}0.001 \\
0.000 \\
0.001 \\
0.001\end{array}$ & $\begin{array}{l}0.004 \\
0.004 \\
0.005 \\
0.004\end{array}$ \\
\hline & & 0.017 & 0.017 & 0.017 \\
\hline
\end{tabular}

Root yield (RY): Data in Table 13 showed significant increase in the values of root yield (TY) of sugar beet plants with increasing rate of applied $N$ with either FYM or PM application. It is also clear that, the values of root yield (RY) were significantly higher for plants treated with PM than for treated with FYM. This data indicate higher stimulation for the growth of sugar beet plants when treated with PM than with FYM at each rate of applied N. These findings coincide with those declared by (Allam et al., 2005), who mentioned that increasing $\mathrm{N}$ fertilizer level raise high value of root and sugar yield.

Sugar yield (SY): Data in Table 13 showed significant increase in the sugar yield of plants as a result of increasing $\mathrm{N}$ application rate. Also, these values were significantly higher for plants treated with PM than for these with FYM.

Table 13. Sugar and root yield of sugar beet as influence by nitrogen and organic fertilizer treatments.

\begin{tabular}{|c|c|c|c|}
\hline $\begin{array}{l}\text { Organic } \\
\text { Manure } \\
\left(21 \mathrm{~m}^{3} / / \text { fed.) }\right.\end{array}$ & $\begin{array}{l}\text { Nitrogen } \\
\text { (kg/fed) }\end{array}$ & $\begin{array}{l}\text { Sugar yield } \\
\text { (t/fed.) }\end{array}$ & $\begin{array}{c}\text { Root yield } \\
\text { (t/fed.) }\end{array}$ \\
\hline FYM & $\begin{array}{c}0 \\
150 \\
250 \\
350\end{array}$ & $\begin{array}{l}2.32 \\
3.82 \\
4.76 \\
4.91\end{array}$ & $\begin{array}{c}10.5 \\
16.33 \\
20.15 \\
20.86\end{array}$ \\
\hline PM & $\begin{array}{c}0 \\
150 \\
250 \\
350\end{array}$ & $\begin{array}{c}3.08 \\
4.88 \\
4.97 \\
5.11 \\
0.0148\end{array}$ & $\begin{array}{l}15.17 \\
22.98 \\
23.12 \\
23.13 \\
0.047\end{array}$ \\
\hline
\end{tabular}




\section{Quality characters}

Sugar: Data in Table 14 showed significant increases in the percentage of sugar in root of sugar beet with increasing application rate of applied mineral $\mathrm{N}$ fertilizer, with either FYM or PM application. It is clear that FYM application significantly increased the percentage of sugar in root as compared with PM, at each rate of applied $\mathrm{N}$.

Purity: Data in Table 14 showed significantly decrease in purity as a result of increasing rate of applied $\mathrm{N}$. also, it is clear that the purity was significantly lower with PM application than FYM application with each rate of applied N.

Potassium: The concentration of $\mathrm{K}$ was significantly increase in root with increasing rate of applied $\mathrm{N}$. in addition, $\mathrm{K}$ increase was significantly higher in plant sown in soil treated with PM than FYM at each rate of applied $\mathrm{N}$.

Sodium: Data in Table 14 showed significantly increase in the levels of $\mathrm{Na}$ in root with increasing rate of applied $\mathrm{N}$. the data also showed significantly higher level of $\mathrm{Na}$ in root of plants sown on soil treated with PM than FYM.

Alfa-amino-N: As shown in Table 14, there were significant increases in the concentration of alfa-amino- $\mathrm{N}$ in root with increasing application rate of mineral $\mathrm{N}$ fertilizer. It is also clear that root of plants sown on soil treated with PM contain significantly higher level of alfa-amino- $\mathrm{N}$ than of these treated with FYM.

These results are in line with that of (EI-Dsouky and Attia, 2004), who found marked reduction in sucrose percentage and increases in impurities ( $\mathrm{Na}, \mathrm{K}$ and alpha -amino $\mathrm{N}$ ) were observed with increasing inorganic $\mathrm{N}$.

Table 14. The average value of sugar, purity, $\mathrm{K}, \mathrm{Na}$ and alfa-amino- $\mathrm{N}$

\begin{tabular}{|c|c|c|c|c|c|c|}
\hline $\begin{array}{l}\text { Organic } \\
\text { Manure } \\
\left(21 \mathrm{~m}^{3} / / \text { fed.) }\right.\end{array}$ & $\begin{array}{l}\text { Nitrogen } \\
\text { (kg/fed) }\end{array}$ & Sugar & Purity & $\mathbf{K}$ & $\mathrm{Na}$ & Alfa-amino- $N$ \\
\hline FYM & $\begin{array}{c}0 \\
150 \\
250 \\
350\end{array}$ & $\begin{array}{l}22.12 \\
23.40 \\
23.64 \\
23.76\end{array}$ & $\begin{array}{l}91.77 \\
90.65 \\
90.34 \\
88.81\end{array}$ & $\begin{array}{l}4.28 \\
4.44 \\
4.68 \\
5.06\end{array}$ & $\begin{array}{l}0.45 \\
0.55 \\
0.69 \\
0.86\end{array}$ & $\begin{array}{l}1.10 \\
1.15 \\
1.36 \\
2.46\end{array}$ \\
\hline PM & $\begin{array}{c}0 \\
150 \\
250 \\
350\end{array}$ & $\begin{array}{c}20.30 \\
21.22 \\
21.48 \\
21.92 \\
0.57\end{array}$ & $\begin{array}{c}91.13 \\
90.32 \\
88.74 \\
88.20 \\
0.11\end{array}$ & $\begin{array}{l}4.34 \\
4.46 \\
4.85 \\
5.11 \\
0.01\end{array}$ & $\begin{array}{l}0.49 \\
0.63 \\
0.89 \\
0.89 \\
0.05\end{array}$ & $\begin{array}{l}1.13 \\
1.18 \\
1.40 \\
2.54 \\
0.05\end{array}$ \\
\hline
\end{tabular}

\section{Soil characterization of plant harvest}

Data in Table 15 showed marked and relative decrease in the values of $\mathrm{PH}$ of soil after plant harvest as compared with these of the original soil (Table 1). The effect of PM on decreasing soil PH was more pronounced than the effect of FYM. On the other hand, the values of EC were increased after plant harvest as compared with the original soil (Table 1). Also, the levels of OM in soils had increases after plant harvest than of the original soil (Table 1). However, there were no marked variations in the level of total $\mathrm{CO}_{3}{ }^{-2}$ in soils before and after plant harvest (Tables 1 and 15). 
Hasanen, G. H. et al.

Table 15. The average value of some characteristics of soil after plant harvest.

\begin{tabular}{lccc}
\hline Parameter & Soil depth $(\mathbf{c m})$ & FYM soil & PM soil \\
\hline PH & $0-15$ & 7.09 & 6.78 \\
& $15-30$ & 7.42 & 7.11 \\
EC(ds/m) & $0-15$ & 0.88 & 0.76 \\
& $15-30$ & 1.11 & 1.11 \\
OM (\%) & $0-15$ & 0.15 & 0.12 \\
& $15-30$ & 1.14 & 0.13 \\
Total $\mathbf{C o}_{3}{ }^{-2}$ (\%) & $0-15$ & 5.13 & 4.92 \\
\hline
\end{tabular}

\section{REFERENCES}

Allam, S.A.H.; K.E. Mohamed; G.S. El-Sayed; A.M.H. Osman (2005). Effect of sowing date, nitrogen fertilizer and row space on yield and quality of sugarbeet crop. Annals. Agric. Sci., Moshtohor, 43(1): 11-24.

A.O.A.C. (1980). Official Methods of Analysis, Association of Official Analytical Chemists, Washington, D.C., USA.

Besheit, S.Y.; M.S. Mona and S.E. Samia (1994).The use of nitrogen for sugar beet grown in sandy soil of Egypt. J. Appl. Sci., 9(2):225-231.

Chapman, H.O. and H. Praft (1961). Methods of analysis for soil. Waters and plants. Univ. California, Division of Agric.

El-Dsouky, M.M.; K.K. Attia. (2004). Effect of mineral, organic and biofertilization on yield and quality of sugarbeet plants. Assiut J. Agric. Sci. 35(3): 161-180.

El-Geddawy, I.H.; M.S. Osman; M.G. Abd EL Fadeil and, A.H.S. EL-Labbody (2003). Effect of some agri-practice on yield and its attributes of sugar beet. Egypt. J. Agric. Res., 8(4):1671-1691.

El-Shafai, A. M. A (2000). Effect of nitrogen and potassium on yield and quality of sugar beet in Sohag. Egypt. J. Agric. Res., 78(2): 759-767.

Gomez, K.A. and A.A. Gomez (1984). Statistical procedures for agricultural research. An international. Rice Research Institute Book. John Willey and Suns, Inc., New York.

Ismail, A.M.A and R.A. Abo El-Ghait (2004). Effect of balanced fertilization of NPK on yield and quality of sugar beet. Egypt. J. Agric. Res., 82(2):717-729.

Kristaponyte, I. (2003). The influence of organic and mineral fertilizers on sugar beet productivity. Zemdirbyste, Mokslo Darbai. 81: 64-72.

Leilah, A.A.; M.A. Badawi; E.M. Said; M.H. Ghonema; M.A.E. Abdou (2005). Effect of planting dates, plant population and nitrogen fertilization on sugar beet productivity under the newly reclaimed sandy soils in Egypt. Scientific J. King Faisal Univ. (Basic and Applied Sciences), 6(1): 95110.

Seadh, S. E.; S. Farouk; M.I. El-Abady (2007). Response of sugar beet to potassium sulfate under nitrogen fertilizer levels in newly reclaimed soils conditions. $8^{\text {th }}$ African Crop Sci. Society Conf., El-Minia, Egypt, 27-31 Oct. pp. 147-153. 


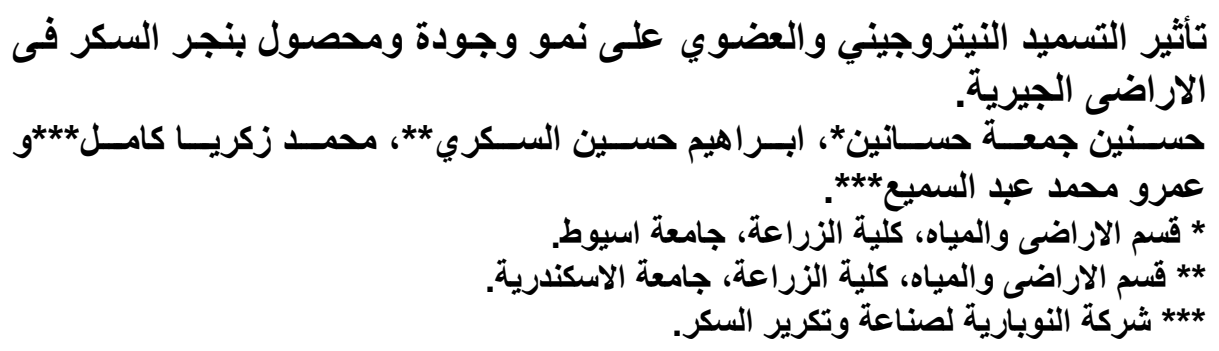

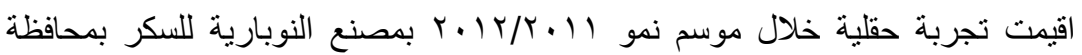

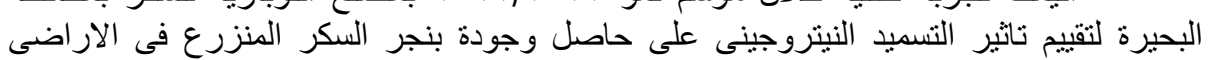

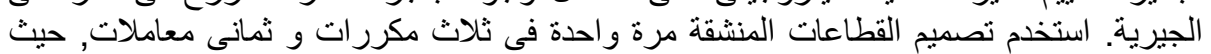
وزعت اربع مستويات للتسميد النيتروجينى فى القطع الرئيسية، في حين خصصت التصن القطع المنشقة

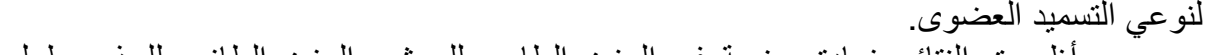

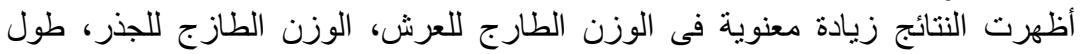

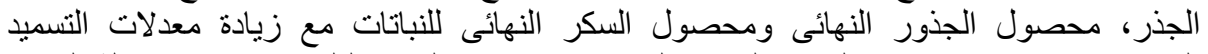

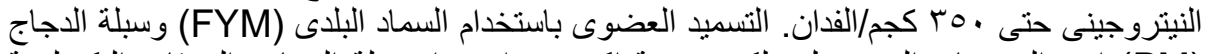

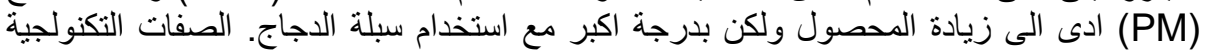

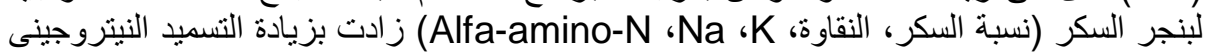

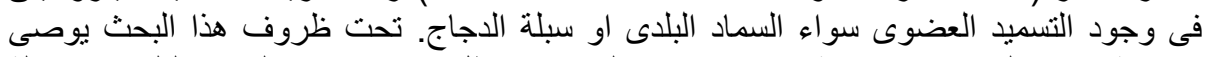

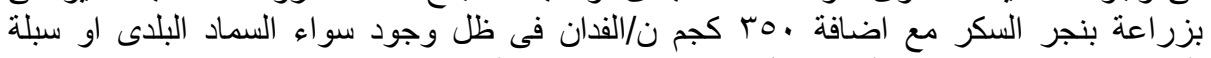
الدجاج، حيث انه اعطى اعلى حاصل جذور وسكر نهائى/الفذان.

كلية الزراعة - جامعة المنصورة

قام بتحكيم البحث

كلية الزراعة - جامعة القاهره

أ أ. أد / محمد نصد البحث الدين الهلالى العزيز

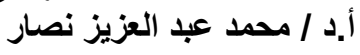

